\title{
Regulatory Consistency in Breaking the Chain of Covid-19 Spread in Indonesia
}

\author{
Rudy \\ Faculty of Law \\ Lampung University \\ Lampung, Indonesia \\ rudy.1981@fh.unila.ac.id
}

\author{
Aprilia Fitri Ningsih \\ Faculty of Law \\ Lampung University \\ Lampung, Indonesia \\ apriliafitri.n@gmail.com
}

\begin{abstract}
The increased number of certified cases of Covid-19 in Indonesia and the many regulations that have been established by the government as a form of prevention and breaking the chain of spread has resulted in the importance of evaluating all actions issued and implemented in Indonesia. This study aims to capture various policy regulations and their application models in health emergencies related to COVID-19. This study uses a normative method by reviewing various existing regulations and using secondary legal materials such as journals and related literature.
\end{abstract}

Keywords-Countermeasures, Regulations, Covid-19

Regulations,

\section{PRELIMINARY}

Coronavirus disease, commonly known as COVID 19, is a new virus discovered in December 2019 in Wuhan, China. Covid-19 attacks continue to occur, as it is known that this virus continues to mutate, giving rise to several new variants that are increasingly worsening the world situation, especially in Indonesia [1]. Based on research, Covid-19 is one of the viruses that started with SARS-CoV-2, thought to have come from bats. This virus attacks part or all of the respiratory tract from the mouth, nose, the lungs.

However, this virus also grows and develops along the walls of the respiratory tract, where the virus spreads so quickly just by splashing the air that comes out of someone who is infected with the virus. This, or what is commonly called a droplet [2].

The most common symptoms that people feel or need to be aware of are coughing, fatigue, loss of sense of taste and smell, and fever of more than $38^{\circ} \mathrm{C}$. Other symptoms that a person with confirmed COVID-19 may feel are sore throat, stuffy nose. The symptoms suffered are the same as the flu in general. This is what makes it difficult to detect early contracting this virus. Some infected people also have only mild symptoms. Most of the infected people managed to recover without special treatment, but not a few people died from this virus [3].

Not yet over this covid 19, this virus continues to mutate; so far, there have been four new variants resulting from the mutation of covid-19, namely, The Alpha variant was first discovered in England [4]. The Beta variant was found in Africa. The Kappa variant was first discovered in India. The Delta variant was first discovered in South Africa. These four variants have a higher transmission potential.

Covid-19 continues to attack all over the world. Victims caused by this virus continue to increase every day from Confirmed Patients to death, so the United Nations and the World Health Organization (WHO) have declared the coronavirus outbreak (Covid-19) a global pandemic so that governments in all countries are asked to take action. Actions to fight the spread of this virus, the Indonesian government is no exception.

In Indonesia, cases of the spread of COVID-19 began to be discovered in 2020, precisely in March Joko Widodo as the President of the Republic of Indonesia announced the discovery of the first case of Covid-19. Since then, the number of confirmed cases has continued to increase with various harmful effects, especially human health. Therefore, the Indonesian government needs to act decisively in combating the quo virus. Therefore, various regulations that are considered appropriate are formed to combat, prevent, and overcome all the consequences caused by this virus.

Talking about national policy is inseparable from the structure of interrelated state institutions in implementing government policy according to needs and government [5]. When Covid19 invaded Indonesia, the Indonesian government took immediate and positive action by enacting Executive Order No. National Disaster.

Related to health problems, several legal regulations in Indonesia were formed long before the existence of Covid 19, which can be used as the basis for the 
issuance of new regulations as a step to prevent the spread of covid 19, including, Law Number 4 of 1984 concerning Infectious Diseases, Law No. Law Number 36 of 2009 concerning Health, and Law Number 6 of 2018 concerning Health Quarantine [6].

Several rules established by the government as steps to prevent and disrupt the Covid19 virus spread chain are in the procedure for enacting the laws and regulations set out in Law No. 12 of 2011. Further investigation is needed to determine if it is in line. The introduction of the law is updated in Law 15 of 2019, which amends Law 12 of 2011 regarding the introduction of the law. Based on this, the government should refer to the relevant regulations when notifying about new regulations as a way to deal with COVID 19. In this case, the Government of Indonesia will refer to Law No. 6 of 2018 on Health Quarantine and Law No. 36 of 2009 on Health as one of the reference rules when drafting new rules to follow up on the issue of Covid 19 in Indonesia. You can refer to. Indonesia. This rule is one of the government's rules long before the Covid 19 incident in Indonesia [7].

Based on the research that the author has done, there are at least 24 regulations that have been formed and approved by the government as a step to overcome and break the chain of the spread of Covid-19. However, these regulations have become a hot topic of discussion in the community, starting from the formation of relatively short regulations to changes to these regulations. This is one of the urgencies of the need for a study on the formation of regulations for dealing with COVID-19 in Indonesia, by mapping policies that have been issued by the government to make it easier for the public to know and also to make it easier for lower-level governments to form special regulations in the regions so that they can help and accelerate the process of controlling and breaking the chain of the spread of Corona Virus Disease 19.

The problems that arise as a result of this virus continue to grow, ranging from the economic sector to the government. So it is necessary to act decisively and quickly to overcome this problem so that it does not worsen the situation. The increase in confirmed cases of Covid-19, which continues to increase in various countries, especially in Indonesia, is an interesting thing to study, starting from what are the factors causing the increase in Covid-19 cases, the form of handling that is taken by the government, specifically in the field of regulation for handling COVID-19, to the implementation of the established rules. Based on the problems above, this paper tries to describe the central government's policies regarding the handling of covid 19 so that what factors affect the increase in cases continue to increase.

\section{DISCUSSION}

Increasing the number of cases infected with Covid19 has resulted in the government being required to be fast and responsive to all problems. Until now, the government continues to strive to overcome and break the chain of the spread of COVID-19 by issuing various regulations as tangible evidence of the government's seriousness in handling, preventing, and breaking the chain of spread. Since March 2021, at least eight essential regulations have been formed as a form of prevention and handling of Covid as a derivative of Law 6 of 2018 concerning Health Quarantine and Law 36 of 2009 concerning Health [8].

The formation of regulations related to the handling and prevention of COVID-19 needs to be studied further, considering that the existing demands have resulted in the process of forming a response regulation being rushed.

Legislation, which is a branch of legal science, has elements that need to be considered. The elements contained in the scientific nature of the science of legislation, among others, must be objective, methodical, systematic, and universal [9].

The object of good legislation needs to meet the requirements of origin (causa), namely the origin of the material (material), the origin of the form (formal), which is following its meaning in written form, and the origin of the process, namely seeing the formation process whether it is following the mechanism. which have been specified [10].

The method used in the formation of legislation is carried out with a juridical normative approach and an empirical sociological approach [11]. The juridical normative approach concerns the method used in the formation of laws and regulations based on the application of written legal norms that are hierarchical, by synchronizing and harmonizing laws and regulations. The empirical sociological approach concerns the method of establishing laws and regulations based on social phenomena of the community which are strengthened by existing legal theories and then abstracted (looking for juridical elements) to be included in a statutory regulation [12].

It is known that the nature of the legislation that is formed is completely binding on the community following the type of regulation that is formed. It is this binding nature that underlies the laws that are formed, which must be obeyed (forced) and known by every community, without exception.

If it is related to the discussion above, it can be seen that the formation of laws related to the handling of COVID-19 needs to be studied starting from the process of its formation, the methods used to the content of the material contained therein. The study of the regulations that were formed as a follow-up to the Covid-19 response is important to know that what is regulated is appropriate and relevant to the conditions that exist in the community so that it can be implemented properly in the community to become a legal umbrella and guide for the community. 
government, or law enforcement officials in tackling the problem of covid-19 [13].

Based on the provisions stipulated in Article 4 of Law 6 of 2018 concerning Health Quarantine, it is explained that;

"The Central Government and Regional Governments are responsible for protecting public health from diseases and/or public health risk factors that have the potential to cause public health emergencies through the implementation of health quarantine."

This article forms the basis for the central and regional governments to work together to overcome and break the chain of the COVID-19 epidemic and establish new regulations that are expected to overcome and eliminate the Covid 19 epidemic chain in the community.

Executive Order No. 11 of 2020, which establishes a health emergency for Coronavirus Disease 19, was issued regarding Article 10 (1) of Law 6, 2018 on Health Quarantine;

"Central government establishes and revokes public health emergencies."

Under Section 15 (2) of Law 6, 2018, there are 4,444 measures that the Government can take to address health issues that may lead to health emergencies. In this case, the Government has issued Government Ordinance No. 21 of 2020 on Massive Social Restrictions, which the Government has chosen as a measure to prevent, control, and stop the spread of COVID 19. Decree No. 21 of 2020 was ratified by Minister of Health Decree No. 9 on Guidelines for Social Restrictions in the Broad Definition, which is a measure taken by the Government to address this chain. It became a further provision regarding the choice of. Of discontinuing proliferation.

Law Number 6 of 2018 concerning Health Quarantine. This law was passed on August 7, 2018, which consists of 14 Chapter 98 Articles. In detail, this law contains general provisions which contain limitations on understanding in the scope of health quarantine, principles for administering health quarantine, Health Quarantine Goals; Central and local government responsibilities in protecting public health from diseases, and public health risk factors where the introduction of quarantine can cause public health emergencies. Some form of community rights and obligations in health quarantine investigations. Penalties for those who violate.

Instead of 2020 Law No. 1 on National Monetary Policy and Financial System Stability to Address the 2019 Coronavirus Pandemic (Covid19), and/or the Economic and/or Financial System. This ordinance was adopted on March 31, 2020, and consists of Chapter 5, Article 29. The Ordinance implements the State's Income and Expenditure Budget (APBN) concerning addressing the pandemic of Coronavirus Disease 2019 (Covid19) and threatening the stability of the economy and financial system. The procedure is regulated, including:

- state revenue policy, including

- policies in the field of taxation,

- state spending policies, including policies in the area of regional finance and financing policies;

- financial system stability policies include policies for handling financial institution problems that endanger the national economy and/or financial system stability.

Decree No. 21 of 2020 on Widespread Social Restrictions This Ordinance was ratified on March 31, 2020, and consists of seven provisions. This rule governs the process of enforcing widespread social restrictions. This is one of the government's decisions to break the Covid-19 epidemic chain. Municipalities, with the consent of the Minister of Health, shall apply for PSBB using the standards set out in this Ordinance, the application for assessment, the assessment procedure, and the implementation of Massive Social Restrictions (PSBB). You can also, the ordinance also includes records and reports, oversight, and guidance in the implementation of PSBB.

Transport Minister Ordinance No. 18 of 2020 on Traffic Control Related to Covid 19 Epidemic Prevention. This regulation was ratified on April 9, 2020, and consists of six Chapter 23 articles. This regulation describes regional transport management, known as large-scale social restrictions. Transport management for return activities in 2020

On Eid Al-Fitr $1441 \mathrm{H}$, the government prevented the spread of Covid-19 through the Minister of Transportation Regulation Number 25 of 2020 concerning Traffic Control in the Hijri Calendar. This rule was adopted on 23 April 2020 and consists of 28 articles. This regulation includes a temporary ban on the use of land, sea, and air transportation to prevent the spread of Covid19. This regulation follows the government's policy of imposing widespread social restrictions, namely avoiding the movement of people and goods, to break the chain of spreading the Covid19 virus and prevent the formation of new clusters.

The government through the minister of health made changes to the Regulation of the Minister of Health Number 10 of 2021 concerning the Implementation of Vaccinations to overcome the 2019 coronavirus pandemic (Covid-19). This Ministerial Regulation serves as a reference for the Government at the Central, Provincial, Regency/City levels, health workers, stakeholders, and the wider community in the implementation of the COVID-19 vaccination program. The scope of Ministerial Regulation no. 10 of 2021 are as follows: 
- Knowing the Vaccine Implementation Process, Vaccine Objectives, planning for COVID-19 Vaccination needs;

- The target of implementing the COVID-19 Vaccination;

- Distribution of COVID-19 Vaccine, supporting equipment, and logistics;

- Implementation of COVID-19 Vaccination services;

- Cooperation in the implementation of COVID19 Vaccination;

- Monitoring and prevention of Adverse Events after COVID-19 Vaccination;

- Communication strategy;

- Recording and reporting;

- Funding; and

- Guidance and supervision

The government made changes to Presidential Regulation Number 99 of 2020 regarding the procurement of vaccines and the implementation of vaccinations to combat the spread of the coronavirus (Covid-19) 2019. This regulation contains the implementation of the procurement of vaccines and the implementation of the COVID-19 vaccination:

- Starting from the procurement of the COVID-19 Vaccine;

- Implementation of the COVID-19 Vaccination;

- Funding for COVID-19 Vaccine procurement and implementation of COVID-19 Vaccination; and

- Support and facilities of ministries, agencies, and local governments.

Presidential Regulation Number 99 of 2020 also stipulates the type and amount of COVID-19 Vaccine required for the implementation of COVID-19 Vaccination. In addition to laws and regulations, the government has also issued several decrees and circulars as a form of handling Covid-19, including Presidential Decree Number 7 of 2020. 2020 concerning the Task Force for the Acceleration of Handling Corona Virus Disease 2019 (Covid-19). This regulation was enacted on March 13, 2020, which consists of 14 articles. This regulation regulates the formation of the Task Force for the Acceleration of Handling Corona Virus Disease 2019 (COVID-19), starting from the person in charge who is in the hands of the President, the purpose of the formation of the task force, the tasks of the task force itself, to the composition of the membership.
On March 20, 2020, the government ratified Presidential Regulation Number 9 of 2020 concerning Amendments to Presidential Regulation Number 7 of 2020 concerning the Covid-19 Handling Task Force. This regulation was set to strengthen the implementation of the Covid-19 task force. This regulation changes two articles of provisions that have been regulated in Presidential Regulation Number 7 of 2020. Some of the amended provisions include the following:

- Article 8 regarding the composition of the Covid Task Force membership

- Article 13 related to Funding which originally only consisted of 1 paragraph, added two new paragraphs that explained the criteria for the funds to be used for handling Covid-19

- Insert 1 article between articles 13 and 14 , namely, article $13 \mathrm{~A}$, which explains the acceleration of the import of goods for the prevention of Covid-19

On March 31, 2020, the government again issued a regulation regarding the health emergency condition due to an increase in Covid-19 cases through Government Regulation Number 11 of 2020. This regulation consists of 3 dictums that contain the determination of Corona Virus Disease 2019 (Covid19) as a type of disease. that causes a health emergency so that efforts are needed to overcome is based on the applicable laws and regulations.

Decree of the Minister of Communication and Information Number 159 of 2020 concerning Efforts to Handle Covid-19 concerning Handling Covid-19 through the postal and information technology sector. This decision was born on March 26, 2020. This decision was born in response to the Secretary-General of Health Letter Number SR.03.04/3/1061/2020 regarding requests for support for the use of information technology as an effort to overcome Covid-19. This regulation consists of 9 dictums containing telecommunications operations with the necessary steps according to the government's request, providing applications related to Covid-19, broadcasting institutions, online media providers, and other media providers carried out by broadcasting institutions to facilitate the public regarding explanations regarding Covid. -19

Presidential Regulation Number 4 of 2020 (Covid19) concerning Restructuring Activities Related to Accelerating Handling of Corona Virus Diseases, Shifting Budgets, and Procurement of Goods and Services, Ministries/Institutions and Regional Governments Reorganizing Activities and Budget Redistribution for the Procurement of Goods and Services in the context of accelerating prevention coronavirus disease 2019 (Covid19). 
Decree of the Minister of Health No. 612/MENKES/SK/V/2010 concerning Guidelines for the Implementation of Health Quarantine in Handling Public Health Emergencies that Troubled the World. Regulates Guidelines for Health Officers from the Puskesmas level to the Provincial Health Office level regarding the Implementation of Health Quarantine in Handling Public Health Emergencies of World Concern and aims to prevent the spread of diseases that have the potential to be a public health emergency that can quickly spread between humans through health quarantine activities at the entrance and at the entrance outside the country entrance.

Decree of the Minister of Health Number: HK.01.07/Menkes/182/2020 concerning Corona Virus Disease (Covid-19) Examination Laboratory Networks Establishes Corona Virus Disease (Covid-19) Examination Laboratory Networks along with Duties, Financing, and Monitoring as one of the actions to detect Covid-19 early.

Minister of Education and Culture Circular Letter Number 3 of 2020 concerning Prevention of Corona Virus Diseases (Covid-19) in Education Units. An appeal to the Heads of Provincial, Regency/City Education Offices, Heads of Higher Education Service Institutions, Higher Education Leaders, and School Principals to guide the prevention of Covid-19 in education units based on the level of risk of spread to break the chain of the spread of Covid-19.

In the explanation of Chapter IX of Law 6 of 2018 concerning Health Quarantine Resources ranging from Health Quarantine Facilities and Supplies, Quarantine Officers, Research and development, to Funding. In Article 72 paragraph (1), it has been stated that what needs to be provided by the government in implementing health quarantine, including;

- Rapid detection and response equipment, Diagnostic room

- Health quarantine hostel

- Isolation Room

- Referral hospital

- Reference laboratory

- Public health emergency evacuation transportation.

The above actions have been taken by the Indonesian government, as evidenced by the imposition of several regulations in the community [14]. As for business actors/business persons in charge of providing Thermonex or temperature measuring devices to detect Covid-19 symptoms. The government has also provided facilities in the form of Rapid Tests to detect it early if someone has symptoms of Covid-19. In addition, the government continues to strive to provide adequate facilities for the community, especially hospitals, which are a reference for the community. Currently, Indonesia has 903 Covid-19 referrals, of which 132 are referral hospitals from the Ministry of Health, and 771 referral hospitals are based on the Governor's Decree [15]. The government has also formed a special agency to handle problems related to Covid-19, known as the Covid-19 Handling Task Force (SATGAS COVID-19), to the form of handling in the form of Vaccination for the community.

Following the provisions contained in article 36 number (1) of Law 36 of 2009 concerning health, it is explained that;

"The government guarantees the availability, equity, and affordability of health supplies, especially essential medicines."

If it is associated with the current conditions, the government is not only required to find a way to break the chain of the spread of the Covid-19 virus so that there are no additional new cases but it is also required to find a solution to cure the victims who have contracted this virus. So far, the government has also made efforts by conducting clinical trials of health supplies to tackle this virus, one of which is the presence of a new vaccine that is expected to be able to overcome and slow the spread of this virus. After going through a long thing finally found a vaccine named Sinovac Vaccine. This is proven on January 13, 2021; the first Vaccination was carried out by President Joko Widodo at the State Palace as one of the actions taken by the government to protect the public [16].

The government's vaccination program aims to suppress the spread and transmission of the coronavirus (Covid-19). In addition, to reduce morbidity and mortality due to the coronavirus (Covid-19), achieve group immunity in society, and help social and economic stability of the community.

From the regulations and policies above, it can also be seen that there are several conflicting policies. One of them is Perppu Number 1 of 2020 which has been ratified as Law Number 2 of 2020 concerning Stipulation of Government Regulations in Lieu of Law Number 1 of 2020. State Financial Policy and Financial System Stability in Handling the 2019 Corona Virus Disease Pandemic and/or in the context of facing threats that endanger the national economy and/or financial system stability becomes an unconstitutional law in Article 12 paragraph (2) which states that changes in the state budget and income in 2020 can be stipulated through a presidential regulation., this is contrary to Article 23 paragraph (1) of the 1945 Constitution which states that:

"The revenue and expenditure budget as a form of state financial management is determined every year by law and is carried out openly and responsibly for the greatest prosperity of the people." 
Article $23 \mathrm{C}$ of the 1945 Constitution also states that matters relating to the state financial system are regulated by law. Referring to this, the state constitution does not state that the revenue and expenditure budget, which is part of state finances, is allowed to be regulated by a mechanism other than the law. So that following Article 7 of Law 12 of 2011 concerning the Formation of Legislation which has been amended in Law 15 of 2019 concerning Amendments to Law 12 of 2011 concerning the Establishment of Legislations which mentions the hierarchy of regulations In Indonesia, the 1945 Constitution as the highest constitution of the country is used as the basis for the formation of regulations under it [17].

Until now, efforts are still being made which are expected to be able to break the chain of the spread of Covid-19 in Indonesia, which continues to increase by implementing Community Activity Restrictions (PPKM) as a follow-up to regulations related to the adaptation of new activities in Indonesia [18].

The regulation related to the Community Activity Restrictions (PPKM) is one of the policies formed to respond to the existing PSBB rules, but this regulation related to PPKM narrows and tightens the community's space to carry out activities to gather large numbers of people, to limiting hours outside the home [19].

Various supervisions continue to be carried out to maximize the government's steps in breaking the chain of spread by imposing Mandatory Antigens and including Vaccine certificates for people who want to move regions to minimize the possibility of spreading this virus. This policy is expected to be carried out consistently by the community as well as the government to obtain maximum results [20].

All regulations issued by the government are following applicable laws and regulations, but in the implementation process, there are regulatory confusions to irregularities committed by the public or government officials. This confusion of regulations formed by the government is what makes the statement that the regulations formed by the government are halfhearted.

Not only that, government officials who are often caught on camera not implementing Large-Scale Social Restriction policies and also not implementing health protocols make people distrust the government. The people's distrust is not without cause because only by clarifying and apologizing are their needs considered finished [21].

Based on this, following the theory put forward by Soerjano Soekanto, one of the efforts made by the government to overcome is by applying strict sanctions for policy violators [23]. The government needs to emphasize and apply sanctions from the rules that have been formed to prevent and break the chain of the spread of COVID-19 in Indonesia because good policies need to be well supported by the whole community so that the purpose of the regulation being formed can be achieved effectively. Maximum as expected.

Apart from regulations, sanctions, community participation is also one of the important things in the enforcement and implementation of the established rules. As we all know that the effectiveness of regulation can be measured, one of which is the compliance of the community itself.

Therefore, to realize the goal of preventing and controlling COVID-19 and to break the chain of government participation, the community has a big role to play [23].

\section{CONCLUSION}

The rules that have been issued by the government are following the laws and regulations in Indonesia that deal with related problems. However, throughout the implementation of the Covid-19 control rules, there are inconsistencies between the content material that has been established by the government, namely the content material contained in Article 12 paragraph (2) of Law Number 2 of 2020 concerning the Stipulation of Government Regulation in Lieu of Law Number 1 of 2020. 2020 State Financial Policy and Financial System Stability for Handling the 2019 Corona Virus Disease Pandemic and/or in the context of dealing with threats that endanger the national economy and/or financial system stability into law, that changes in the state budget posture can be stipulated through a presidential regulation.

\section{SUGGESTION}

Based on the explanation above, it can be seen that the prevention and eradication of COVID-19 can not only be done through existing regulations but also needs support from all Indonesian people to implement a clean lifestyle by maintaining distance, wearing masks, and washing hands. Government officials need to be firm in implementing sanctions for Covid-19 violators.

In addition, the government needs to emphasize and apply sanctions from the rules that have been formed to prevent and break the chain of the spread of COVID-19 in Indonesia because good policies need to be well supported by the whole community so that the purpose of the regulation being formed can be achieved optimally as expected.

\section{REFERENCES}

[1] https://Covid.go.id

[2] Ministry of Helath Republic of Indonesia. SARS-CoV-2 Serang Seтua Bagian Paru-paru. May 11, 2020. Retreived from https://www.kemkes.go.id/article/view/20051100001/sarscov-2-serang-all-section-lung.html/

[3] WHO. Pertanyaan dan jawaban terkait Coronavirus. Retreived from https://www.who.int/indonesia/news/novelcoronavirus/qa/qa-for-public 
[4] N. R. Aida. Inilah 10 varian baru virus corona hasil mutasi, kenali gejala dan cara mencegahnya. June 10, 2021. Retreived from https://kesehatan.kontan.co.id/news/inilah-10-varianbaru-virus-corona-hasil-mutasi-kenali-gejala-dan-caramencegahnya?page $=$ all

[5] I. W. Wiryawan. Kebijakan Pemerintah Dalam Penanganan Pandemi Virus Corona Disease 2019 (Covid-19) Di Indonesia." Prosiding Webinar Nasional Universitas Mahasaraswati Denpasar 2020. 2020. 179-188.

[6] A. G. Sari. Kebijakan pemberlakuan karantina wilayah sebagai antisipasi penyebaran corona virus ditinjau dari undangundang no. 6 tahun 2018 tentang kekarantinaan kesehatan. Transparansi Hukum 3(2). 2020.

[7] Law Number 6 of 2018 concerning Health Quarantine. Jdih.bssn.go.id/arsip-law/uu-number-6-year-2018-aboutquarantine-health

[8] D. Telaumbanua. The Urgency for the Establishment of Regulations Related to Covid-19 Prevention in Indonesia. Journal of Social and Religious Education, Vol. 12 No. 1. 2020.

[9] Rudy. Reconstruction Of Legal Development In Indonesia: Laws On Land. Faculty of Law. University of Lampung. 2013.

[10] Rudy, Y. Hasyim, and Siti Khoiriah. Social justice assessment model in the formation of regional regulations. Lampung: Faculty of Law. 2013.

[11] Rudy. Law of Local Government Perspective of Indonesian Constitutionalism. Lampung: In-depth Publishing. 2012.

[12] Rudy. Constitutionalism in Indonesia, Center for the Study of Constitution and Legislation (PKKPUU). Faculty of Law, University of Lampung. 2013.

[13] B. Manan. Constitutional Fundamentals of National Legislation. Padang: Faculty of Law, Andalas University. 1994.

[14] C. Saputra, and P. I. Driposwana. Empowerment of Covid-19 Response for Health Workers", Journal of Character Education Society, Vol. 3, No. 2, July 2020.
[15] Ministry of Health. Covid-19 Isolation Spaces in All Provinces Are Still
Kemenkes.go.id/article/view/20101300001/Space-isolationcovid-19-di-all-provinces-Masih-adequate.html

[16] https://www.kompas.com/sains/read/2020/06/12/19020223/sa at-vaksin-covid-19-discovered-who-yang-pertama-getkannya?page=all.

[17] A. F. Ningsih. Consistency of Regulations in Handling Covid19 in Indonesia Based on Legislation. Thesis. University of Lampung, 2021.

[18] D. Herdiana. Coping with COVID-19 at the Local Level Through the New Habit Adaptation Policy (IMR) in West Java Province. Journal of Governance Innovation, Vol. 2 No. 2. 2020.

[19] T. S. Hashanah. The Effectiveness of Large-Scale Social Restrictions in Indonesia in Overcoming the Covid-19 Pandemic. journal.uinjkt. Vol 4, No 1. 2020.

[20] P P. L. Oka. Problematics of the Application of the Regional Quarantine System and PSBB in Coping with Covid-19. Kertha Semaya Journal, Vol. 8 No. 9. 2020.

[21] N. N. Pujaningsih, IGAAG Dewi Sucitawathi P. Implementation of the Policy for Restricting Community Activities (PKM) in Combating the Covid-19 Outbreak in Denpasar City”, Unigal Journal, Vol.6 No.3. 2020.

[22] R. H. Pakpahan. Criminal Law Policy as an Effort for Covid19 Emergency Management. National Law Magazine, Vol. 50 No.2. 2020

[23] U. Rosidin, R. Laili, H. Erna. Behavior and Role of Community Leaders in Prevention and Management of the Covid-19 Pandemic in Jayaraga Village, Garut Regency. Indonesian Journal Of Anthropology, Vol. 5 No. 1. 2020. 